(2) Open Access Full Text Article

LETTER

\title{
Hemogram parameters for predicting pulmonary embolism in patients with deep venous thrombosis
}

This article was published in the following Dove Press journal:

Therapeutics and Clinical Risk Management

6 November 2015

Number of times this article has been viewed

\author{
Hakki Kaya \\ Recep Kurt \\ Department of Cardiology, \\ Cumhuriyet University Medical \\ School, Sivas, Turkey
}

\section{Dear editor}

We read the article of Sevuk et al, ${ }^{1}$ published in the August 2015 issue of your journal, with great interest. The authors concluded that percentage change in serial measurements of mean platelet volume (MPV) and platelet-distribution width (PDW) is valuable in predicting the development of pulmonary thromboembolism in patients with a previous history of deep venous thrombosis (DVT). In a similar study conducted by Braekkan et $\mathrm{al}^{2}$ (Tromsø Study), MPV on admission was shown to predict pulmonary thromboembolism.

In a study by Zorlu et al, ${ }^{3}$ red cell-distribution width (RDW) values $>14 \%$, which is another parameter included in complete blood count, were associated with increased risk of mortality in the early period after pulmonary thromboembolism. RDW can be easily measured in routine hemograms, and indicates changes in erythrocytedistribution width. ${ }^{4}$ Certain inflammatory cytokines released in response to acute heart failure occurring in acute pulmonary embolism may cause an increase in RDW values through inhibition of erythrocyte maturation by affecting bone marrow. ${ }^{5-7}$ It is realized that the study by Sevuk et $\mathrm{al}^{1}$ did not include RDW in statistical analysis. Considering the fact that RDW has been previously documented to increase mortality in pulmonary thromboembolism, ${ }^{3}$ we suggest that RDW may be increased in patients with DVT due to acute pulmonary embolism and associated acute right heart failure and thus play a role in predicting the development of pulmonary embolism.

In conclusion, $\mathrm{RDW}$, which is measured in routine hemograms together with MPV and PDW, is an easy parameter to access, so authors might include RDW in statistical analysis. We think that if RDW levels were used for this study together with MPV and PDW, RDW might change the results of multivariate analysis and might be one of the predictors of pulmonary embolism in patients with DVT.

\section{Disclosure}

The authors report no conflicts of interest in this communication.

\section{References}

1. Sevuk U, Bahadir MV, Altindag R, et al. Value of serial platelet indices measurements for the prediction of pulmonary embolism in patients with deep venous thrombosis. Ther Clin Risk Manag. 2015;11:1243-1249.

2. Braekkan SK, Mathiesen EB, Njølstad I, Wilsgaard T, Størmer J, Hansen JB. Mean platelet volume is a risk factor for venous thromboembolism: the Tromsø Study, Tromsø, Norway. J Thromb Haemost. 2010;8:157-162. 
3. Zorlu A, Bektasoglu G, Guven FM, et al. Usefulness of admission red cell distribution width as a predictor of early mortality in patients with acute pulmonary embolism. Am J Cardiol. 2012;109:128-134.

4. Karnad A, Poskitt TR. The automated complete blood cell count. Use of the red blood cell volume distribution width and mean platelet volume in evaluating anemia and thrombocytopenia. Arch Intern Med. 1985;145:1270-1272.

5. Felker GM, Allen LA, Pocock SJ, et al. Red cell distribution width as a novel prognostic marker in heart failure: data from the CHARM Program and the Duke Databank. J Am Coll Cardiol. 2007;50:40-47.
6. Hampole CV, Mehrotra AK, Thenappan T, Gomberg-Maitland M, Shah SJ. Usefulness of red cell distribution width as a prognostic marker in pulmonary hypertension. Am J Cardiol. 2009;104:868-872.

7. Pierce CN, Larson DF. Inflammatory cytokine inhibition of erythropoiesis in patients implanted with a mechanical circulatory assist device. Perfusion. 2005;20:83-90. 


\section{Authors' reply \\ Utkan Sevuk' \\ Mehmet Veysi Bahadir² \\ Rojhat Altindag ${ }^{3}$ \\ Erkan Baysal ${ }^{3}$ \\ Baris Yaylak ${ }^{3}$ \\ Nurettin $\mathrm{Ay}^{4}$ \\ Firat Ayaz' \\ Ertan Demirtas ${ }^{5}$}

'Department of Cardiovascular Surgery, Diyarbakır Gazi Yașargil Education and Research Hospital, ${ }^{2}$ Department of General Surgery, Dicle University, ${ }^{3}$ Department of Cardiology, ${ }^{4}$ Department of General Surgery, Diyarbakır Gazi Yașargil Education and Research Hospital, Diyarbakır, ${ }^{5}$ Department of Cardiovascular Surgery, Liv Hospital, Ankara, Turkey

Correspondence: Utkan Sevuk

Diyarbakir Gazi Yasargil Egitim ve Arastirma

Hastanesi, Kalp ve Damar Cerrahisi Klinigi,

3 kat, Uckuyular, Diyarbakir 21010, Turkey

Tel +905055307095

Email utkansevuk@gmail.com

\section{Dear editor}

We read with great interest the letter to the editor written regarding our article, and appreciate the opportunity to respond to the letter. ${ }^{1}$

Red blood cell-distribution width (RDW) is an easily available and affordable laboratory test that measures variation in red blood-cell size or red blood-cell volume. Recent studies have shown that elevated RDW was associated with the mortality rate of many disease states. Zorlu et al found that high RDW was associated with worse hemodynamic parameters and increased risk of mortality in patients with acute pulmonary embolism (PE). ${ }^{2}$ In a study by Cay et al, RDW was reported to be associated with the presence and severity of deep venous thrombosis (DVT). ${ }^{3}$ Additionally, a recent report by Bucciarelli et al associated elevated levels of RDW with risk of venous thromboembolism. ${ }^{4}$

We agree that RDW may be associated with PE in patients with DVT, and may play a role in predicting the development of PE in patients with DVT. In future research, we plan to include RDW in our experimental design.

\section{Disclosure}

The authors report no conflicts of interest in this communication.

\section{References}

1. Sevuk U, Bahadir MV, Altindag R, et al. Value of serial platelet indices measurements for the prediction of pulmonary embolism in patients with deep venous thrombosis. Ther Clin Risk Manag. 2015;11:1243-1249.

2. Zorlu A, Bektasoglu G, Guven FM, et al. Usefulness of admission red cell distribution width as a predictor of early mortality in patients with acute pulmonary embolism. Am J Cardiol. 2012;109:128-134.

3. Cay N, Unal O, Kartal MG, Ozdemir M, Tola M. Increased level of red blood cell distribution width is associated with deep venous thrombosis. Blood Coagul Fibrinolysis. 2013;24:727-731.

4. Bucciarelli P, Maino A, Felicetta I, et al. Association between red cell distribution width and risk of venous thromboembolism. Thromb Res. 2015;136:590-594.

Dove Medical Press encourages responsible, free and frank academic debate. The content of the Therapeutics and Clinical Risk Management 'letters to the editor' section does not necessarily represent the views of Dove Medical Press, its officers, agents, employees, related entities or the Therapeutics and Clinical Risk Management editors. While all reasonable steps have been taken to confirm the content of each letter, Dove Medical Press accepts no liability in respect of the content of any letter, nor is it responsible for the content and accuracy of any letter to the editor.

\section{Publish your work in this journal}

Therapeutics and Clinical Risk Management is an international, peerreviewed journal of clinical therapeutics and risk management, focusing on concise rapid reporting of clinical studies in all therapeutic areas, outcomes, safety, and programs for the effective, safe, and sustained use of medicines. This journal is indexed on PubMed Central, CAS,
EMBase, Scopus and the Elsevier Bibliographic databases. The manuscript management system is completely online and includes a very quick and fair peer-review system, which is all easy to use. Visit http://www.dovepress.com/testimonials.php to read real quotes from published authors. 